\title{
The Problematics of Gender and Power in Lumban Traditional Hand Embroidery
}

Kristine Kalaw-Adalla

\begin{abstract}
Embroidery provides meaningful discoveries through interactions and relations connected in the lived experiences of women hand embroiderers. A woman's performance of her embroidery skills indicates the intimate connection of her womanhood, her daily life, and the kind of labor and effort she places upon it. Interviews, focus group discussions, and creative workshop reveal that social conditions from the past to the present, allow her to continuously construct her identity and negotiate her role in society. Embroidery has offered the women in this study an opportunity to create not only their identity as individuals but also as a community, and has helped them develop their capacities beyond realizing their womanhood. The presence of the problematics of gender and power is evident through the obvious contradictions of the empowered under disempowering conditions thus rendering their power and empowerment, symbolic.
\end{abstract}

Keywords: embroidery, identity construction, empowerment, power dynamics, gender performance 


\section{Plaridel Open Access Policy Statement}

As a service to authors, contributors, and the community, Plaridel: A Philippine Journal of Communication, Media, and Society provides open access to all its content. To ensure that all articles are accessible to readers and researchers, these are available for viewing and download (except Early View) from the Plaridel journal website, provided that the journal is properly cited as the original source and that the downloaded content is not modified or used for commercial purposes. Plaridel, published by the University of the Philippines College of Mass Communication is licensed under Creative Commons Attribution-NonCommercial-NoDerivatives 4.0 International License (https://creativecommons.org/ licenses/by-nc-nd/4.0/legalcode).

\section{How to cite this article in APA}

Kalaw-Adalla, K., (2021). The problematics of gender and power in Lumban traditional hand embroidery. Plaridel, 18(1), 181-201. https/doi.org/10.52518/2021.18.1-02kadall 
In a small corner of her home, I see trophies and awards. When she saw me looking at them, she proudly told me about the time when she won a local contest. She didn't want to join because she didn't believe she would win, but her son encouraged her... and this encouragement gave her confidence. When she received her award, her exceptional mastery and skill in embroidery was validated. And she couldn't be any prouder of herself.

Field Notes, KKAdalla

\section{Introduction}

Femininity was to be lived in terms of specific domestic responsibilities (Parker, 2010) and embroidery used to be in the domestic sphere. Embroidery used to be for personal use and as an "expression of their innate domesticity" (p. 138). But by the end of seventeenth century to the end of nineteenth century, the women embroiderers' shift from the household to the labor sector began. During this period, embroidery largely shifted to the hands of working-class women or disadvantaged middle-class women ( $\mathrm{p}$. 5). Embroidery was then called "work" and evoked the notion that patience and perseverance go into embroidery (p. 6). Thus, the ideology of femininity as service and selflessness and the insistence that women work for others, not for themselves, surfaced (Parker, 2010).

\section{The shift from household to labor market}

According to Maria Asuncion Faronillo (2013), the fine and exquisite skill of Filipino embroiderers was acknowledged by other countries, and the Philippines became famous for its embroidery. She added that by the turn of the century, as Spanish colonization ended, the embroidery industry was still on the rise and when the Americans came, the industry continued to grow and gained its full potential. They supported and continued the tradition of educating women in needlecraft thus, the School of Household Industries was established to provide training for particular women of different provinces (2013). She writes that these women were expected to learn extensively and have sufficient knowledge after graduation so they could start an industrial center in their provinces (2013). The students were taught not only the skills in embroidery and lace making but also concepts 
on economy of time and motion, market value of products, commercial design, and business processes within six to eight months (de la Torre, 2000).

Women embroidered to earn extra money especially in places where there was no field or factory work available. Filipino women and their daughters (some sons too) took to embroidery with a flair and with more than considerable enthusiasm (de la Torre, 2000).

As the garment industry progressed, the huge amount of embroidered goods for export made by Filipino women proved the importance of their role in the economic development of the country. Americans observed that Filipinas showed signs of independence because of their urge to improve the economic status of their families (Peralta, 2015).

The subsequent years saw a proliferation of garment firms in the country. This further accelerated the development of embroidery from a humble home-craft to a multimillion peso industry (de Vera, 1989). With the introduction of fast-paced electric sewing machines in the 1970s, embroidery rapidly developed into a gigantic industry (de Vera, 1989). The machines enabled the mass production of embroidered items especially for the export industry.

With the fast-growing garment industry, women's placement as embroiderers was reframed. Their embroidery was no longer for personal and family use but for mass production. From a leisure activity, it became work and it required not only time and skills, but production efficiency and meeting deadlines. While many women worked as laborers in big garment factories, others stayed at home and made hand-embroidered products for their clients. This shift from household to the labor force changed the dynamics of the household. Men were not the only ones earning and providing for their family; women gained a venue to help contribute to family coffers.

The new situation altered the notion that men should be the breadwinners and the women, caretakers within a heterosexual household. Traditionally, "women depend on their husbands for the provision of food, shelter and protection whereas men depend on women for the bearing and rearing of children and the maintenance of the home and men themselves" (Becker, 1991, p. 43).

\section{Methodology}

This study employed a narrative and participatory approach in exploring the lived experience of 14 women hand embroiderers in Lumban, Laguna, with varied ages ranging from thirteen to eighty-five years old when it was conducted. Interviews, focus group discussions, and a creative workshop were done in understanding how these women hand embroiderers from 
different generations construct and perform their gender and identity in their everyday lives.

\section{Results and Discussion}

Along the course of my conversations with the women, one mentioned, "Kapag taga-Lumban ka, dapat marunong kang magburda" (If you're from Lumban, you must know how to embroider). Everybody agreed as if it was a necessary thing for them. They take pride in their town being the embroidery capital of the Philippines;

and somehow there is a responsibility attached to it as being the core of their industry-as being embroiderers.

Field Notes, KKAdalla

\section{Barong as a pivotal factor in the transformation of Lumban household embroidery to labor}

The barong tagalog was crucial in transforming Lumban embroidery from a cottage industry into a labor intensive industry. The shift of patronage in embroidered products from church to secular life began as soon as the barong gained popularity among politicians after the Second World War (de Vera, 1989). The demand for the garment increased and it reframed the placement of women hand embroiderers from the household to the labor market. Moreover, women no longer produced embroidered pieces for themselves and for members of their family but for another person-a consumer/buyer, and for another gender-the male. This changed the dynamics of the female craft as it transitioned to an industry. Women became alienated from the craft and the embroidery industry became only a means to earn their upkeep. Lumban, having been known for traditional hand embroidery, was one of the municipalities affected by these changes.

The barong, as Ma. Corazon Alejo-Hila et al. (2008) put it, is an extension of race memory. Every time a Filipino puts on a barong, he renews his connection with the past, his experiences, and reminds Filipinos who they are. As a product of tradition and culture, the barong tagalog has evolved and served as the symbol of colonialism and at the same time, patriotism.

Alejo-Hila et al. (2008) reveal that making a fine barong takes at least 452 days - from producing the piña fabric, preparing the loom, weaving, embroidery, etc. No wonder the barong commands admiration. They 
further explain that as the barong is worn, the wearer does not just "throw it on or peel it off." The traditional barong opens down to the waist with not enough room to slip on the garment with ease. In fact, the wearer needs assistance to put it on properly. As it is worn, he raises his arm as another person assists and glides the garment into place, and the same motion in reverse is done to take it off. The person being dressed or undressed lifts his arms up in the air as if in surrender, relinquishing control. The barong, it seems, lays down its own terms where the wearer has no choice but to abide by them.

Once worn, the barong takes over and the wearer transforms into someone better than himself. The moment the garment touches his skin, bit by bit, a fresh image is revealed. He becomes more handsome, transforms even more psychologically as he walks taller with his spine stiffer, he glitters and conducts himself with the politeness of diplomats. Thus, the barong is not for the mousy, clumsy, and rude. In turn the man wearing the barong is received with respect and regarded as a man above others. It has the power to elevate even the most ordinary person, and as a ritual dress in death, it endows the wearer with enough dignity to meet his Maker. (Alejo-Hila et al., 2008, p. 26-27)

Alejo-Hila et al. (2008) explain that the barong as garment of ritual is but an extension of the barong as garment of race memory. As mentioned by poet Virginia Moreno:

Costume is our second skin. Our body with its clothes on is so much part of each other, so intimately sewn together by many colored threads, actual or unseen, that at one point of our lives their joint seams melt to become one and the same skin. What clothes we put on are what we are and we are what we put on. (Alejo-Hila et al., p. 28)

This, perhaps, is what happened when the Filipino first wore the barong-the garment "melted" into his skin, so that the garment and he became one, according to Alejo-Hila et al. (2008). Every time the Filipino puts on a barong, he renews his connection with the past-with the pintado whose tattoos expressed his identity and innate spirituality, with the other realities of the national experience. Thus, the barong reminds Filipinos of who they are (Alejo-Hila et al., 2008). 
As the barong evolved and became a product of colonialism and at the same time, patriotism, it becomes essential to discuss how women, the ones who make these garments, are caught up in its development.

The proliferation in the use of the barong tagalog served to change women's status in society. Apart from the economic stability that it provided for the family, it enabled them to express and empower themselves. Even without formal education, they felt their worth and it resonated, not just in the way they dealt with the constraints of their womanhood, but in their embroidered works as well. Leony said, "Kahit hanggang Grade 1 lang ang natapos ko, masasabi ko naman na maayos naman ang buhay ko. Kumikita pa rin ako kahit wala akong pinag-aralan. Marangal itong trabaho ko at nakikilala kami kapag may pumupunta rito." [Even if I only finished Grade 1, I can say that I have had a good life. I am still earning even though I did not study. I have a decent job and we get to be recognized when people come here (to Lumban)]. Melissa said, "Nagustuhan ko na rin itong pagbuburda kasi at least nakakatulong ako sa asawa ko kahit nasa bahay lang ako. Pag wala siyang uwi (money) hindi kami magugutom." [I began to like embroidery because at least I get to help my husband even if I am just at home. When he can't bring in the money, we don't go hungry]. For Cynthia, her sense of self-worth has extended in her embroidery work as she explained, "May tiwala kasi ako sa sarili ko na kaya kong makagawa ng magandang tahi kaya masarap sa pakiramdam noong nanalo ako sa contest dati. Kapag may tiwala ka sa sarili mo, lalabas din yun sa burda at bibilhin talaga yung gawa mo. Minsan ipapatulad pa sa iba yung design na ginawa mo." [I have selfconfidence that I can execute a beautiful [piece of] of embroidery, I felt good when I won a contest before. If you have self-confidence it will manifest in your work and people will surely buy. Sometimes, like some others, they will copy the design you created].

The barong is a not just a symbol of colonialism and patriotism. It is not just a ritual dress that evokes culture and tradition. It is also a symbol of masculinity, social status, and power. As earlier cited, as a man dons a barong he undergoes transformation, he becomes more confident and is received with respect and regarded as a man above others. This transformation is the effect of historical associations and the meticulous process that the barong undergoes. The amount of time spent working on a piece of barong and the careful execution of designs are among the essential factors that are put forth into this evocation of power in the garment. And women embroiderers are at the center of this equation because aside from the quality of fabric, the intricate embroidery designs influence the perception of power emanated by the garment-as in Philippine colonial times when the mestizo ensured that his dress was more elite than that of the ordinary indio. 


\title{
Barong and women's symbolic power
}

A woman creates something and it becomes a part of herself. A woman creates something and it contains a part of herself.

Field Notes, KKAdalla

\begin{abstract}
Power is not static; rather, it is remade at various junctures within everyday life, rearticulated through everyday social relations. The aim is to gain an edge, accepting compromises, if needed, in the process of contesting and redefining both the scope of universal norms and the meanings attributed to particular roles and identities. (Rao, 2012, p. 1026 ).
\end{abstract}

A man wearing a barong undergoes transformation within himself. $\mathrm{He}$ is received with respect, he becomes more confident, and he exudes power as he wears a barong (Alejo-Hila, et al., 2008). Deconstructing this conventional perspective, we can infer that this power and transformation of a man, as he wears a barong, is symbolically reinforced by the women who created it. A patriarchal society accepts the realization of manhood in a heterosexual marriage if a man can sire a child, and this ability to sire a child is fulfilled by a woman as she gives birth to his child. Sometimes, it does not matter which woman it is; as long as he can father a child, he has realized the entirety of his manhood. Stephan Miescher (as cited in Ampim, 2020) states that "having biological children and performing the roles of a father, such as providing for a wife, children, and kin, were significant in attaining dominant masculine ideals" (Ampim, et. al. 2020, p. 28). At the same time, the realization of womanhood is when a woman becomes a mother, so long as she sincerely wants to be one. As Roszkia Parker (2010) noted, "femininity was to be realised in child-bearing and child-rearing" (p. 128).

This "power" that is projected by men, is in reality, a coexisting with women and at times, emanates from women. This notion is manifested in what Salvador, Leony's husband, told me when he said, "Ang asawa ko talaga, siya talaga ang dahilan kung bakit hindi ako napunta sa bisyo. Kahit noon nasa malayo ako nagtatrabaho, palagi niya ako sinasabihan kaya hindi ako nambabae, nagsugal." [My wife is really the reason why I did not succumb to vices. Even before when I was working far from here, she always reminded me, that is why I did not have other women and I did not gamble]. Genesis, Cynthia's son, on the other hand, says that he doesn't know what he would do without the guidance of his mother. He says, "Naku, baka po sa kangkungan kami pulutin." [We might go astray and become worthless). 
These statements reinforce the power that women have in the lives of these men].

The barong is not only an extension of race memory but an extension of the lives of the women who created it. When a woman creates an embroidered piece, in this case a barong, she leaves a part of herself in the final product. She leaves an imprint of not only her skills in embroidery but also her experiences, memories, and thoughts. Parker (2010) states that "embroidery even in its simplest form may become the expression of personal thought and feeling, as it is work which mirrors a woman's own thought and personality" (p. 202). Interviews revealed that when a woman works on a piece of embroidery, her emotional state affects the stitches and overall design of the cloth. As Joy shared the times when her work would be a total disaster because she is angered or raging about something:

Minsan talaga, Ma’am, talagang ang pananahi ko, disaster eh! Talagang pangit ang gawa pagka minsan galit ka. Pag halimbawa galit ako sa anak ko, yung hila ko [ng sinulid] laging matigas. Minsan kahit matigas yung karayom, napuputol. Minsan nahiwa na rin ako ng blade. Lagi rin akong natutusok kapag nananahi ng masama ang loob.

[There are times when my work is a disaster! The work really turns ugly when one is raging. For example, if I'm mad at my child, I pull at the thread so tightly. At times, even though the needle is sturdy, it breaks. There are also times when I cut myself with a blade. I am sure to get pricked often when I work with baggage inside me].

Consequently, her identity is also embedded in the embroidered work as she freely creates her own designs and patterns. Therefore, a man in barong, is not only wearing a national costume, or a ritual dress, he is also symbolically donning the life of the woman embedded in the barong.

The barong, though masculine, has woman power in it, and this power helps reinforce that transformation; they are treated with respect because of that power. However, this power, to which women contribute the transformation and masculinity of the male as he wears a barong, is invisible because as a male parades the barong, his masculinity is evoked without reference to the woman who created it. This power coming from the woman is completely dissolved and what is visible to others is only the power of the dominant male on the surface. As the backbone of the industry, they remain anonymous as the ones who get the recognition for the finished product are the designers and merchants. I asked them what they felt when others got 
recognized for their work. Their unanimous response was that they were proud of their work. However, they are willing to give up this recognition and for them, it did not matter anymore as long as they got paid for it. Cynthia said in her interview, "Proud na proud ako sa sarili ko, Ma'am, kasi si PNoy suot-suot niya yung tinahi ko, nakita ko sa TV. Pero ganun talaga, hindi na mahalaga sa akin yung malaman ng iba na ako ang gumawa nun. Basta sa sarili ko, proud ako." [I'm very proud of myself because I saw on TV PNoy (President Noynoy Aquino) was wearing my work. It's not important anymore whether other people know that I was the one who made it. I know it and I am just proud of myself]. While famous designers get recognition for their work, the woman embroiderer's invisibility is magnified and she creates in herself an acceptance that her situation is beyond her control.

\title{
Women's economic power in family dynamics
}

\author{
Embroidery has given meaning to the \\ lives of women hand embroiderers such \\ that many of them wish to have their own \\ embroidery shop someday. \\ Field Notes, KKAdalla
}

In understanding how women hand embroiderers in Lumban (re) construct their identity through embroidery, it is important to understand how they perceive their work and themselves, and how this perception operates in the woman's sense of self-empowerment.

Margaret Whetherell (1996) sees work as a major part of an individual's identity in the sense that it influences the way a person perceives himself/ herself and how others perceive him/her. In constructing and understanding their identity as women embroiderers, I wanted to know how they perceived hand embroidery, how their families valued their craft, and how all of this affected the women's self-concept. How their self-concept was constructed in relation to embroidery was crucial to the understanding of their identity.

All of the respondents in my study consider embroidery an important aspect of their lives mainly because of the financial benefits it provides them. All of them agreed when Leony stated that "Napakaimportante po sa amin ang pagbuburda kasi dyan kami kumikita ng pera, dyan kami kumukuha ng kabuhayan." [Embroidery is very important to us because it is where we earn, that is what we depend on for our living]. Anda Manic maintained that it was through embroidery that she and her husband were able to send all their children to college and up until now, she helps some of her grandchildren financially in their schooling. "Yung mga anak ko, napagtapos ko lahat yan 
ng college dahil sa pagbuburda. Tulungan kami ng asawa ko. Yung ibang apo ko, tinutulungan ko rin sila sa bayarin sa eskwela nila" [I was able to send all my children to college because of embroidery. My husband and I helped each other. Until now, I help my other grandchildren in their school expenses], she says. Maria narrates that she needs to embroider because her family would not get to eat a decent meal if she does not work. Her children still live with her despite having families of their own. They usually share the finances but most of the time she is the one who is burdened with shouldering the needs of the entire family. "Wala naman akong magagawa, Ma'am. Hindi ko rin naman sila matitiis. Kaya kayod na lang habang kaya pa" [I really cannot do anything. I can't just ignore them, either. So I work hard until I can], she narrates. Cristine mentions that embroidery is her main source of income and that her family gets by each day because of the earnings from her job. She tells me, "Napakaimportante po ng pagbuburda sa akin dahil dito ko kinukuha lahat-pambayad sa ilaw, pambili ng bigas, ulam, pambayad sa eskwela ng mga anak ko." [Embroidery is very important for me because it provides for our daily needs-payment for electricity, to buy rice and viand, and payment for school fees of my children].

As for the family members of the women involved in my study, they too considered embroidery as an important part of their lives. Genesis, the son of Cynthia, explained that when his father got into an accident which left him disabled, it was through embroidery that they were able to survive. Salvador, the husband of Rose, explained that embroidery is their breadand-butter since he did not have a regular job. For these families, the value of embroidery in their life is anchored on the financial support that it brings them.

This is why I decided to find out how they valued the women in their lives and to see if this had an effect on the self-concept of the women involved in this study.

I found that their husbands and children give them utmost respect and value them as wives and mothers. They state that it is these women who bring up their children, send them to school, keep the family intact, and take care of them when they are sick. Raising children, taking care of the entire family, making sacrifices for the family, and giving unconditional love are some of the reasons why their family members deem these women as important in their lives. Salvador mentions in his interview that he values her wife for everything she is. He is amazed at how Rose does everything. He explains, "Siya talaga ang bumuo ng aming pamilya, nagpalaki sa aming mga anak, nagpatapos sa kanilang pag-aaral hanggang 4th year [high school]. Hindi kasi regular ang trabaho ko." [She is the one who kept our family intact, reared our children, she sent them to school until they finished 4th 
year. The reason is I don't have a regular job]. Genesis, on the other hand, admires his mother, Cynthia, for taking the role of both mother and father when his father died few years ago. "Alam ko po mahirap din yung ginawa niya na siya ang nanay at tatay naming magkakapatid. Siya po ang bumuhay sa amin kaya mahalaga po si nanay sa amin." [I know that it was difficult what she did both as and father to us. She provided for us and we cherish her]. The guidance provided by their mothers and wives has given their family members direction in life and allowed them to see the importance of valuing each other.

There is no doubt that these women get their encouragement and inspiration to work hard from their families. Everything they do is for their family, sometimes extended families. The hardships they undergo are not put to waste because they have appreciative family members who know and value the hard work that these women embroiderers exert-in order for them to survive together. During the interviews on the subject of family, their eyes gleamed with pride and joy when they heard what their families had to say about them. Rose was unable to hold back her tears. Winning contests for something you worked hard for, being recognized for your efforts as breadwinner of the family, being appreciated for the sacrifices of a mother for her children-these are reasons that boost their self-confidence, provide inspiration to continue working hard, and the determination to strive for survival. This is when the embroiderer sees a positive reflection of herself in her work and in the perception of her work by others. As Parker (2010) puts it, "Embroidery promotes and reflects a richer, more meaningful internal world, which is in turn substantiated by the perception of the work in the outside world" (p. xx). Winning contests and seeing her designs replicated promote a sense of capacity to create something, a self-validation that indeed she is worth something.

For the women who participated in my study, being able to help support the family financially is self-empowering. They see the importance and value of their work and their self-worth because they also help bring food to the table. Cristine mentions that it is very important for her to be able to support her family and be able to send her children to school. She takes pride in knowing that she is the one providing for their family. Leony also takes pride knowing that she can provide for the family since her husband does not have a regular job. She has grandchildren whom she supports and the income she gets from embroidery helps in these situations. "Masarap rin po sa pakiramdam yung alam mong natutulungan mo yung pamilya mo, yung mga anak mo, kahit pa sabihin na may pamilya na rin sila" [It is also a wonderful feeling to be able to help your family, your children, even if they already have their own families], she says. 
Justine and Sam, being the younger ones, see embroidery as an important aspect of their lives because it helps them get by in their education. They get their daily allowance, payment for school projects, and are able to buy school supplies from their income through embroidery. Joy even mentioned that Justine is the one paying for their electricity or water bill sometimes. This sense of responsibility and being able to help the family is giving Justine a sense of pride. She proudly tells me,

"Minsan nga nagungutang pa ako diyan pag kulang ang pambayad ko sa kuryente. Hindi na rin yan nahingi sa akin ng pambaon sa school. Nung isang beses nakasama siya sa field trip dahil sa ipon niya. Kung wala naman yun hindi naman siya makakasama dun."

[There are times when I would borrow money from her (Justine) when I don't have enough to pay for our electricity bill. She also doesn't ask for money from me for her school allowance. Once, she was able to join their field trip because of her savings. If she did not have that she would not have been able to join].

Hand embroidery is a daily activity for these women. Being full-time, stay-at-home mothers, their domain has become the home and their role is to nurture the children, which extends to the grandchildren for some of them. This is the reason why hand embroidery is the perfect opportunity for them to earn and help in household finances.

The fact that women hand embroiderers provide economic stability in the family enables them to negotiate their power in the household. Decision making is shared among household members and, of course, the woman has a voice in it. However, this power negotiation is confined only within the household because the current set-up in the informal labor market (no benefits, job security, medical assistance, etc.) does not allow her to experience this power outside her family dynamics. Most of the time, these women workers are in no position to negotiate the price of their labor since the businessmen and managers dictate the terms of their job orders and price of labor, thus leaving them disadvantaged. As Joy said, "Sila (managers) ang nagbibigay ng presyo. Pepresyuhan nila tapos kukunin na lang naming kahit mababa ang presyo." [They (managers) give the price. The dictate the price and we'll just accept even if the price is low]. The power structure outside the home does not do justice to the hours of labor and mastery of skills that go into each embroidered piece. The ascendancy of her manager supersedes the power she exercises in her household because she is unable to negotiate 
her position. Furthermore, while her power at home is visible, it is quite the opposite when she is surrounded by people she considers to be above her social status. Nila expressed this further, "Minsan nahihiya rin kami makisalamuha sa kanila [managers] kasi, iba nga no na sila ... kumbaga, ibang level. Mataas na sila kasi kumbaga, sila na yung nagluluwas ng tahi. Kami lang po yung manggagawa, ganun." [There are times we would feel shy and uncomfortable socializing with them (managers) because they are on a higher level than us. They are the ones bringing the items to Manila while we are just workers]. She loses all confidence and sees herself as inferior to them.

Marx's conflict theory best explains this situation with the women involved in my study. "Marx's concern was with a group's sense of deprivation caused by class. This sense of deprivation is what leads a group to class consciousness and produces conflict and social change" (Dahrendorf, 2006, p. 216). Using contemporary conflict theory, these women can be considered to be under Relative Deprivation where there is a "sense of being underprivileged relative to some other person or group" (p. 216).

Marilou Carillo (2003) propounds that social construction in a colonial environment is unstable because "the relationship, by not representing difference and equality, is resolved by subordinating one of the pair to the other" (p. 2) and implies relationships of superiority and inferiority, and of hierarchies that mesh with political economies of domination and subordination. For centuries, Filipinos were under the dichotomous relationship of superior masters and inferior servants. Later generations, who were finally able to break free from the colonizers, however, would inherit the same social construction. In present times, globalization has taken the place of colonization and the same hierarchical, dual relationship remains intact. Consequently, this has led to present-day women workers going through the same subversion, only in a different form. 


\section{Women hand embroiderers' symbolic or constructed sense of empowerment}

She was full of pride when she told me the people from Divisoria liked her design and asked her to replicate it and make more of the same pieces. Her eyes were beaming with joy and contentment-a validation of herself... Field Notes, KKAdalla

A woman's embroidery skills show the intimate connections of her womanhood, her daily life, and the kind of labor and effort she places in the embroidery. It is not only a craft-a product of skillful execution by pulling thread-and-needle and putting together designs onto a fabric. It is also a venue of self-expression, which has provided these women an opportunity to negotiate their position within the home.

Embroidery is highly valued by the women who participated in my study. For the most part, that is because it provides them with economic opportunities. Apart from this, however, it also furnishes them a sense of pride and self-empowerment.

Joy and Justine are proud of their work because they get to showcase their skills in the craft, they get recognized because of their work, and they are able to help their town. They are usually among the town's representatives when media networks like ABS-CBN and GMA visit Lumban to do a feature story on embroidery. Cynthia shares the same pride when she narrates, "Kapag nakakatapos ako ng isang tahi masaya ako. Kasi gawa ko yan. Minsan babalik yung may-ari 'O parisan niyo to.' Yung ginawa mo nagustuhan sa Divisoria, gagawa ng panibagong ganito. Malimit na maparisan yung mga ginagawa kong design." [I feel happy when I finish a piece. Because I made it. Sometimes the client would come back and tell the other embroiderers to copy the design I made because the store in Divisoria liked it. The designs I make are often reproduced].

Every year, they have a local contest showcasing their embroidery pieces and Cynthia has won several times. This gives her pride and encouragement to do better in her craft. Justine and Sam, despite being teenagers, perceive embroidery as the better option to spending time on gadgets or hang out with friends. As Justine puts it, "Kaysa po itutok namin ang mata at kamay namin sa gadget o cellphone, sa tahi na lang po." [Instead of keeping our eyes glued to gadget or cellphone, we'd rather focus on embroidery]. Sam added, "Sayang din po yung oras na masasayang kaysa po tatambay. Mas 
mabuti po yung may ginagawa." [Instead of wasting time hanging out, it's better to be productive].

Justine's grandmother, Aling Siony, is proud of her because she is not a typical teenager. She knows the importance of helping the family, even at an early age, and she also takes good care of her responsibilities in school while doing embroidery in her free time. She says, "Proud na proud ako diyan sa batang yan [Justine]. Hindi siya kaparehas ng ibang bata na mas gusto tumambay, mag-gadget. Pag-uwi niyan galing eskwela gagawa yan ng assignment tapos mananahi." [I am so proud of her. She's not like other kids her age who likes to hang out and use gadgets. When she gets home from school, she does her homework and then she would embroider]. In fact, Justine sees herself being in the embroidery business even after she finishes her education. She said in her interview, "Nakikita ko po yung sarili ko na tatanda na nagtatahi pa rin po. Pag nakatapos po ng pag-aaral, minsan magbuburda pa rin po habang naghihintay ng trabaho. Kung suswertehin, magkaron ako ng sariling tahian." [I can see myself growing old and embroidering. When I finish school, I will still embroider while waiting for jobs. If I get lucky, have my own embroidery shop]. Justine's mother, Joy, says that she dreams of having her own embroidery shop one day and hopes to see Justine build that dream with her.

With few of the younger generation wishing to participate in this industry because of its seeming backwardness, Justine and Sam are the hope of the industry and the town's legacy as they are the ones who will continue the tradition of Lumban embroidery. At a young age, they see the importance and need to preserve this heritage and if they can maintain their passion and inspire their peers to learn the skills in embroidery and pursue it, there will be minimal threat for the industry to perish. However, in order for this to happen, the younger women need to realize that it is an industry worth pursuing. This, in turn, requires enlightened policies that will protect embroiderers and liberate them from the present subjugating conditions of this industry.

A source of self-empowerment comes from the prestige that their work has brought them. The works of Cynthia and Rose have been repeatedly found to be excellent as known designers from Metro Manila ask for their services in producing the barong. Justine and her mother were featured in GMA-7 Kapuso Mo with Jessica Soho, while others were featured in ABSCBN's Umagang Kay Ganda. At times, their managers express preference for their original creations and ask for replication and this brings them immeasurable pride. Cynthia tells me,'Nung isang beses ma'am nagustuhan nung manager ko yung gawa ko, ako lang ang nagdesign nun. Nagustuhan daw sa Divisoria kaya ipinapaulit sa akin. Nakaka-proud ba sa pakiramdam 
na yung gawa ko nagugustuhan ng ibang tao." [My manager liked my work which I personally designed. Those in Divisoria liked it too so they want me to produce the same design again. I feel proud that other people appreciate my work].

They also consider hand embroiderers as more skilled than machine embroiderers because of the craftsmanship involved. They also take pride in the fact that they are part of the town's long history of embroidery. "Proud rin po kami kasi kilala talaga sa ibang lugar yung burdang Lumban. Alam nila na kapag gawang Lumban, maganda yan" [We feel proud because Lumban embroidery is known even in other places. They know that if it's made from Lumban, it's good quality], Cynthia says.

Aside from self-empowerment, the camaraderie and connections they build with other women embroiderers in the community allow them collective empowerment and to look out for each other. Embroidery in these communities is a social activity. One seldom sees an embroiderer working alone; they always work in groups. The relationships they build enable them to help each other in different aspects of their social and personal lives. Angie narrates, "Puyatan na yan ma'am kapag may deadline kami. Minsan alas tres na kami natutulog. Kaya minsan tulungan na lang talaga. Kapag tapos na yung isa, tutulungan naman yungisa para makatapos din siya." [We stay up late especially if we have a deadline. Sometimes we finish at three in the morning. We just help each other. When the one is done with her work, she helps the other finish hers].

Nila shares that embroidery brought her closer to her neighbors in the area. After transferring to Lumban when she married a local, she did not know anyone and she did not know how to embroider. It was her neighbors who taught her and since then, she grew fond of the craft. From a housewife with no income of her own, she was able to generate income to help her family through embroidery. Further, she values the friendships she has struck with the other women in her community. She said,

"Nung bago ako dito sa kanila [community], hindi talaga ako marunong manahi. Wala naman rin akong kakilala rito. Basta tinawag lang nila ako tapos simula nun nanood na ako sa kanila hanggang sa natuto na rin ako manahi. Eh di imbes na wala akong ginagawa, kumikita ako ng pera, nakakatulong ako sa asawa ko. Tsaka masaya po ako kapag nananahi kasama sila. Siyempre yung asawa ko naman po wala, kasi nasa trabaho. May nakakasama ako kahit wala siya." 
[When I was still new to this community, I really didn't know how to embroider. I also didn't know anyone. I just joined them one day, I watched and eventually I learned. Now, instead of doing nothing, I get to earn money and help my husband. Besides, embroidering with them makes me happy since my husband is always away, working. At least I have people with me even if my husband is not here].

Their friendship also resonates in extending help whenever personal problems arise. Through moral support, they empower each other in a way that they are not really aware of.

\section{Conclusion}

Embroidery has offered the women in this study an opportunity to create not only their identity as individuals but also as a community and has helped them develop their capacities beyond realizing their womanhood. Having the same experiences, these interactions with each other strengthen and maintain their relationships. More importantly, these interactions give them strength in facing their own battles. These are women not privileged to have everything they want, but they certainly have what they need to survive and that is enough for them to keep on striving. From individual identities, they are able to form their collective identity through their communal involvement in the craft.

From these narratives, we see the way embroidery reinforces the notion that women are relational-that within the sphere of their role, their nurturing behavior manifests in their relationship not only with their families, but also with friends, and coworkers. The bond that embroidery forges between these women allows them to work together without feeling that they are neglecting their role in the family. They use their time productively and maintaining independent social bonds with other women does not mean disregard of their husbands or children.

By looking deeper into the situations of the women who participated in my study, the presence of the problematics of gender and power is unmistakable. Essentially, the contradictions of the empowered under disempowering conditions can become confusing. Therefore, selfempowerment and their power vis à vis the informal labor set-up that they are part of, can be considered as superficial and found only on the surface, in the front stage of Goffman's (1956) stages of performance.

Essentially, in wearing the barong, women's power is symbolic as it is completely dissolved and unrecognized because of the projection of the masculine power on the surface. Consumers no longer look beyond the 
finished product, that is, women's life embedded in the barong. In terms of family dynamics, women's power is negotiated and she continuously does so as she is financially contributing to the needs of the family. In terms of her sense of empowerment as evidenced by their statements, it can be considered as mediated (by the state) since they are named Embroidery Capital of the Philippines. This recognition in itself instills pride and empowerment to the local people. As this is a tradition passed from generation to generation, these notions of sense of pride and empowerment have been also handed down to them historically and sociologically although with differing contexts (craft versus industry). 


\section{References}

Alejo-Hila, M. C., Acuilar-Reyes, M. M., \& Feleo, A. (2008). Garment of honor, garment of identity. A Barong Filipino, Inc.

Ampim, G. A., Haukenes, H. and Blystad, A. (2020). Making fathers: Masculinities and social change in the Ghanian context. Africa Today, 67(1), 24-47.

Becker, G. (1991). A Treatise on the family, $2^{\text {nd }}$ Enlarged edition. Cambridge, MA: Harvard University Press.

Carillo, M. (2003, April). The colonizer/colonized dichotomy: Is that all there is? [Paper presentation]. Women's Studies (WMST) 500 Spring Symposium. http://edocs.lib.sfu.ca/ccrc/html/CCRC_PDF/Coloniz erColonizedDichotomy(MarilouCarrillo).pdf

Dahrendorf, R. (2006). Conflict and critical theories. https://us.corwin.com/sites/default/files/upm-binaries/13636_Chapter7.pdf

de Vera, M. N. (1989). A comparative study of traditional and modern modes of embroidery in Batangas and Bulacan [Unpublished master's thesis]. UP Diliman College of Arts and Letters.

dela Torre V. R. (2000). The Barong Tagalog then and now. Tower Book House.

Goffman, E. (1956). The presentation of self in everyday life (Monograph No. 2). University of Edinburgh Social Sciences Research Centre, George Square, Edinburgh.

Faronillo, M. G. (2013). Current developments in Lumban's embroidery industry [Unpublished undergraduate thesis]. UP Diliman College of Home Economics.

Miescher, S. (2005). Making men in Ghana. Indiana University Press.

Parker, R. (2010). The subversive stitch: Embroidery and the making of the feminine. Women's Press Ltd. (Original work published in 1984).

Peralta, JP. V. (2015). Risen opportunity: The economic role of Filipino women during the American regime. https://nhcp.gov.ph/risen-opportunity-the-economic-role-of-filipino-women-during-theamerican-regime/://nhcp.gov.ph/risen-opportunity-the-economic-role-of-filipino-womenduring-the-american-regime/

Rao, N. (2012). Male providers and female housewives: A gendered co-performance in rural North India. Journal of Development and Change, 43(5), 1025-1048.

Whetherell, M. (1996). Identities, groups, and social issues. Sage Publications. 


\section{Grant Support Details}

Author Contributions: All research activities and writing were done by Adalla, Kristine. The author has read and agreed to the published version of the manuscript.

Funding: The author received no specific funding for this work.

Acknowledgements: The author would like to thank all the women that participated in the study for their time and commitment, as well as her mentors in UP Diliman and UP Los Baños for their valuable insights in the study.

Conflict of Interest: The author declares no conflict of interest.

\section{About the Authors}

KRISTINE KALAW - ADALLA is an Assistant Professor at the Department of Humanities, College of Arts and Sciences, University of the Philippines Los Baños and currently the Coordinator of the LITE (Language Instruction Towards Excellence) Program of the College of Arts and Sciences in UPLB. She obtained her Master's degree in Speech Communication at the University of the Philippines Diliman. (corresponding author: kkadalla@up.edu.ph) 
